\title{
Sorption isotherms of Brazil nuts
}

\author{
Fernando M. Botelho ${ }^{1}$, Nilso J. Boschiroli Neto' ${ }^{1}$, Silvia de C. C. Botelho², \\ Gabriel H. H. de Oliveira ${ }^{3} \&$ Michele R. Hauth $^{4}$
}

${ }^{1}$ Universidade Federal de Mato Grosso/Instituto de Ciências Agrárias e Ambientais. Sinop, MT, Brasil. E-mail: fernando_eaa@yahoo.com.br - ORCID: 0000-0002-
7024-4268; jose.boschiroli.neto@gmail.com - ORCID: 0000-0001-6395-1362
${ }^{2}$ Embrapa Agrossilvipastoril. Sinop, MT, Brasil. E-mail: silvia.campos@embrapa.br (Corresponding author) - ORCID: 0000-0002-2689-5303
${ }^{3}$ Instituto Federal do Sudeste de Minas Gerais. Manhuaçu, MG, Brasil. E-mail: gabriel.oliveira@ifsudestemg.edu.br - ORCID: 0000-0002-6066-9262
${ }^{4}$ Universidade Federal da Grande Dourados/Programa de Pós-Graduação em Engenharia Agrícola. Dourados, MS, Brasil. E-mail: michele.r.hauth@hotmail.com
- ORCID: 0000-0001-6808-5811

\begin{abstract}
Knowledge of the water sorption phenomenon in Brazil nut seeds will allow proper handling of this product, especially with regard to adequate conditions for safe storage. Thus, the present study aimed to determine the sorption isotherms (desorption and adsorption) of Brazil nuts, fitting different mathematical models to the experimental data, as well as to examine the hysteresis effect. To obtain the sorption isotherms, the static method was employed at temperatures of $25,35,45$ and $55^{\circ} \mathrm{C}$ and air relative humidities varying from 10 to $80 \%$. The psychrometric conditions of the air were acquired with the aid of acid solutions and specific saturated saline left inside desiccators with the samples. It was verified that for a given isotherm, the equilibrium moisture content of Brazil nuts increases with water activity increment. In addition, at a constant water activity, equilibrium moisture content decreases with temperature increase. The Copace, Henderson and Oswin are the models that best describe the hygroscopicity of the Brazil nut seed for both the adsorption and desorption processes. Hysteresis was more pronounced at lower temperatures and higher values of water activity. The moisture content value for storage at temperatures less than $55^{\circ} \mathrm{C}$, without the risk of fungal development, must be lower than $8.2 \%$ (d.b.).
\end{abstract}

Key words: Bertholletia excelsa, moisture content, hysteresis, mathematical modeling

\section{Isotermas de sorção de castanha do Brasil}

RESUMO: O entendimento dos fenômenos de sorção de água em sementes de castanheira do Brasil permitirá manejar adequadamente esse produto principalmente no que se refere às condições adequadas para um armazenamento seguro. Assim, objetivou-se determinar as isotermas de sorção (dessorção e adsorção) de água de castanha do Brasil, ajustando-se diferentes modelos matemáticos aos dados experimentais, além da histerese. Para a obtenção das isotermas de sorção foi utilizado o método estático, nas temperaturas de 25, 35,45 e $55^{\circ} \mathrm{C}$ para umidades relativas do ar variando entre 10 a $80 \%$. As condições psicrométricas do ar foram obtidas colocando-se no interior de dessecadores materiais higroscópicos, soluções ácidas e salinas saturadas específicas. Verificou-se que para uma dada isoterma, o teor de água de equilíbrio da castanha do Brasil aumenta com a elevação da atividade de água. Além disso, para uma dada atividade de água, o teor de água de equilíbrio diminui com a elevação da temperatura. Os modelos Copace, Henderson e Oswin são os que melhor descrevem a higroscopicidade das sementes de castanheira do Brasil, tanto na adsorção quanto na dessorção. A histerese foi mais pronunciada nas menores temperaturas e para maiores valores de atividade de água. O teor de água que se deve armazenar a castanha em temperaturas menores que $55^{\circ} \mathrm{C}$ sem que haja risco de desenvolvimento fúngico deve ser menor que $8,2 \%$ (b.s.).

Palavras-chave: Bertholletia excelsa, teor de água, histerese, modelagem matemática 


\section{INTRODUCTION}

The Brazil nut tree (Bertholletia excelsa) is a species that occurs in highlands across the Amazon Basin. Its seed is one of the major forestry products aside from wood, and its importance encompasses both ecological and social issues (Bayma et al., 2014).

Bolivia is the leading exporter of Brazil nuts, which are the dehulled product with the highest market value, corresponding to approximately $60.4 \%$ of the world market share, while Brazil is responsible for $4.5 \%$ (FAO, 2017). However, in 2009, Brazil was responsible for $64.1 \%$ of worldwide exportation of Brazil nuts in their integral form (with the hull), while Bolivia was the main buyer. This difference in products exported with and without the hull is due to the low technology involved in the production chain in Brazil and lack of information regarding post-harvest procedures for this product, including conservation.

Variables that assure the correct conservation of a grain or seed (moisture content, for instance) are determined using knowledge of the relationship between the product, the temperature, and the water activity of the product or the relative humidity of the air at equilibrium (Corrêa et al., 2014, 2015).

This trend is extremely relevant, because in agricultural products, air is used in the procedures of post-harvest handling (e.g., cleaning, drying, aeration and cooling). Because these products are hygroscopic, studies of the sorption phenomenon are important in order to guarantee conservation and quality maintenance during handling.

Considering that the pre-processing and storage stages are critical to the microbiological safety of Brazil nut seeds, the objective of the present study was determining and modeling the adsorption and desorption isotherms of Brazil nuts under different psychrometric air conditions.

\section{Material and Methods}

Brazil nut seeds were obtained directly from harvesters in the municipality of Alta Floresta, MT, Brazil, in the 2016-2017 season, with initial moisture content of approximately $38.0 \%$ (d.b.). Some of the Brazil nut seeds with the initial moisture content were used for the desorption process, and the remaining seeds were dried at $60{ }^{\circ} \mathrm{C}$ and $8 \%$ air relative humidity to a moisture content of $2.0 \%$ (d.b.) for the adsorption process.

The static method was used to obtain the equilibrium moisture content for both the adsorption and desorption processes. Samples were put inside desiccators containing the Brazil nuts, acid solutions and specific saturated salt solutions (Table 1) that provided the desired air relative humidity according to the temperature. The relative humidity of the air is equal to the water activity of the product when the product and air reach the hygroscopic equilibrium. Temperature control was accomplished by keeping the desiccators inside B.O.D. chambers regulated at temperatures of $25,35,45$ and $55^{\circ} \mathrm{C}$. This temperature range was evaluated because it comprises those used to store and dry the Brazil nut seeds in nut-producing regions. Equilibrium conditions are presented in Table 1.
Table 1. Air relative humidities (decimal) established inside the desiccators at different solutions and air temperatures in order to determine the hygroscopic equilibrium of Brazil nut seeds by means of the static method

\begin{tabular}{lcccc}
\hline \multirow{2}{*}{ Solution } & \multicolumn{4}{c}{ Air temperature $\left({ }^{\circ} \mathbf{C}\right)$} \\
\cline { 2 - 5 } & $\mathbf{2 5}$ & $\mathbf{3 5}$ & $\mathbf{4 5}$ & $\mathbf{5 5}$ \\
$\mathrm{H}_{2} \mathrm{SO}_{4}$ & 0.10 & 0.10 & 0.10 & 0.10 \\
$\mathrm{LiCl}$ & 0.23 & 0.19 & 0.16 & 0.16 \\
$\mathrm{MgCl}{ }_{2}$ & 0.36 & 0.34 & 0.32 & 0.31 \\
$\mathrm{CaCl}_{2}$ & 0.43 & 0.44 & 0.44 & 0.45 \\
$\mathrm{Na}_{2} \mathrm{Cr}_{2} \mathrm{O}_{7}$ & 0.65 & 0.66 & 0.64 & 0.62 \\
$\mathrm{NaCl}_{\mathrm{NH}} \mathrm{Cl}$ & 0.71 & 0.72 & 0.70 & 0.71 \\
$\mathrm{NH}_{4} \mathrm{Cl}$ & 0.80 & 0.79 & 0.78 & 0.77 \\
\hline
\end{tabular}

The experiment was carried out in a 4 (temperature) $\times 7$ [air relative humidity (between 0.1 and 0.8 ) ] $\times 2$ (sorption condition) factorial scheme, according to a completely randomized design, with three repetitions using $40 \mathrm{~g}$ of the product.

During the sorption processes, the mass of the samples was periodically measured. Hygroscopic equilibrium was achieved when variation between three consecutive measurements was $\leq 0.01 \mathrm{~g}$.

Moisture contents were determined by the gravimetric method using an oven at $105 \pm 1{ }^{\circ} \mathrm{C}$ for $24 \mathrm{~h}$ (Brasil, 2009).

Mathematical models traditionally used to predict the hygroscopicity of agricultural products were fitted to the experimental data for the equilibrium moisture content (Table 2).

To evaluate the adjustment of the models to the experimental data, the coefficients' significance by the $t$ test (at $\mathrm{p} \leq 0.01$ ), the

Table 2. Mathematical models used to describe the sorption isotherms of Brazil nut seeds

\begin{tabular}{|c|c|c|}
\hline Model name & Model & \\
\hline Chung Pfost & $\mathrm{Ue}=\mathrm{a}-\mathrm{b} \ln [-(\mathrm{T}+\mathrm{c}) \ln (\mathrm{aw})]$ & (1) \\
\hline Copace & $\mathrm{Ue}=\exp [\mathrm{a}-(\mathrm{bT})+(\mathrm{caw})]$ & (2) \\
\hline GAB & $\mathrm{Ue}=\frac{(\mathrm{abc} a w)}{[(1-\mathrm{c} \mathrm{aw})(1-\mathrm{c} \mathrm{aw}+\mathrm{bc} \mathrm{aw})]}$ & (3) \\
\hline Modified Halsey & $\mathrm{Ue}=\left[\frac{\exp (\mathrm{a}-\mathrm{bT})}{-\ln (\mathrm{aw})}\right]^{\frac{1}{\mathrm{c}}}$ & (4) \\
\hline Modified Henderson & $\mathrm{Ue}=\left\{\frac{\ln (1-\mathrm{aw})}{[-\mathrm{a}(\mathrm{T}+\mathrm{b})]}\right\}^{\frac{1}{\mathrm{c}}}$ & (5) \\
\hline Henderson & $\mathrm{Ue}=\left[\frac{\ln (1-\mathrm{aw})}{-\mathrm{a}(\mathrm{T}+273)}\right]^{\frac{1}{b}}$ & (6) \\
\hline Oswin & $\mathrm{Ue}=\frac{\mathrm{a}+(\mathrm{bT})}{\left(\frac{1-\mathrm{UR}}{\mathrm{aw}}\right)^{\frac{1}{\mathrm{c}}}}$ & (7) \\
\hline Sabbah & $\mathrm{Ue}=\mathrm{a}\left(\frac{\mathrm{b} \text { aw }}{\mathrm{T}^{\mathrm{c}}}\right)$ & (8) \\
\hline Sigma Copace & $U e=\exp \{a-(b T)+[\operatorname{cexp}(a w)]\}$ & (9) \\
\hline
\end{tabular}

Ue - Equilibrium moisture content, \% d.b.; aw - Water activity of the product or air relative humidity, decimal; $\mathrm{T}$ - Temperature, ${ }^{\circ} \mathrm{C}$; a, b, and c - Adjustment coefficients that depend upon the model 
coefficient of determination value $\left(\mathrm{R}^{2}\right)$, and the values of mean relative error $(\mathrm{P})$ and standard error (SE), in addition to the analysis of the residual distribution were considered. The values of SE and P were calculated using Eqs. 10 and 11, respectively.

$$
\begin{aligned}
& \mathrm{SE}=\sqrt{\frac{\sum(\mathrm{Y}-\hat{\mathrm{Y}})^{2}}{\mathrm{DFR}}} \\
& \mathrm{P}=\frac{100}{\mathrm{n}} \sum\left(\frac{|\mathrm{Y}-\hat{\mathrm{Y}}|}{\mathrm{Y}}\right)
\end{aligned}
$$

where:

$$
\begin{array}{ll}
\mathrm{n} & \text { - number of experimental observations; } \\
\mathrm{Y} & \text { - observed value; } \\
\hat{Y} & \text { - value calculated by the model; and, }
\end{array}
$$

DFR - degrees of freedom of the residue of the model.

\section{Results AND Discussion}

Except for the GAB model, the remaining mathematical models used to describe the hygroscopicity of Brazil nuts showed significance in their coefficients by the t test (Table 3 ).

The GAB model presented the lowest value of $\mathrm{R}^{2}$. However, the coefficient of determination is not a reliable decisionmaking tool for non-linear models, and it is shown in the present work as a complementary index (Madamba et al., 1996; Goneli et al., 2010).

A model shows a satisfactory adjustment to the experimental data when the mean relative error $(\mathrm{P})$ is less than $10 \%$ (Mohapatra \& Rao, 2005; Henao et al., 2009; Rosa et al., 2010). While the mean relative error indicates the percentage of the average error present in the model, the standard error (SE) indicates the average error of the model at the same physical units of the variable used in the study; in this case, moisture content. Thus, a maximum standard error in the model of $1 \%$ (d.b.) was considered acceptable, the same criteria used by Corrêa et al. (2014). That being stated, while analyzing these two statistical indices ( $\mathrm{P}$ and SE), it is noticed that the $\mathrm{GAB}$ model was inadequate to represent the hygroscopicity of Brazil nuts.

While the remaining evaluated models, in general, presented lower error values when estimating observed data, the Chung-Pfost, Modified Halsey, Modified Henderson, Sabbah and Sigma-Copace models presented a biased distribution of the residues in their estimates in at least one of the processes studied (adsorption or desorption).

Residue distribution consists of the difference between the observed values and the estimated values created by the models. Models were considered adequate when residual values were close to the horizontal line around zero, indicating a random distribution. When the residual values show a biased distribution, the model is inadequate to represent the sorption isotherm studied (Corrêa et al., 2014, 2015).

Examples of random and biased distributions observed during the modeling procedure are presented in Figures $1 \mathrm{~A}$ (Copace) and B (Sabbah).

The Copace, Henderson and Oswin models showed a random distribution of residues under the current sorption conditions evaluated. When added to the results of the remaining statistical indices, it is concluded that these models were the best fitting to the experimental data and should be recommended to describe the sorption isotherms of Brazil nuts.

Among the recommended models, the Copace model was chosen to represent the sorption isotherms of Brazil nut seeds. This model has frequently been recommended in similar studies, such as for seeds of the forage radish (Sousa et al., 2013); fruits of the crambe (Costa et al., 2013) and

\begin{tabular}{|c|c|c|c|c|c|c|c|}
\hline \multirow{2}{*}{ Model name } & \multicolumn{3}{|c|}{ Coefficients } & \multirow{2}{*}{$\begin{array}{c}\text { SE } \\
\text { (\% d.b.) }\end{array}$} & \multirow{2}{*}{$\begin{array}{c}P \\
(\%)\end{array}$} & \multirow{2}{*}{$\begin{array}{c}\mathrm{R}^{2} \\
(\%)\end{array}$} & \multirow{2}{*}{ RD } \\
\hline & a & b & C & & & & \\
\hline & \multicolumn{7}{|c|}{ Desorption } \\
\hline Chung-Pfost & $23.8768^{*}$ & $4.1446^{*}$ & $29.021^{*}$ & 0.6067 & 6.735 & 96.74 & $\mathrm{R}$ \\
\hline Copace & $1.4555^{\star}$ & $0.0074^{*}$ & $1.7293^{*}$ & 0.4857 & 5.776 & 97.91 & $\mathrm{R}$ \\
\hline $\mathrm{GAB}$ & $4.9792^{\star}$ & 20.0676 & $0.7845^{\star}$ & 0.9245 & 10.510 & 92.43 & $\mathrm{R}$ \\
\hline Modified Halsey & $4.0271^{\star}$ & $0.0134^{\star}$ & $1.9310^{\star}$ & 0.6354 & 7.525 & 96.72 & B \\
\hline Modified Henderson & $0.0002^{*}$ & $32.1677^{*}$ & $1.8738^{*}$ & 0.5609 & 6.389 & 97.21 & $\mathrm{R}$ \\
\hline Henderson & $0.00004^{*}$ & $1.8442^{*}$ & - & 0.8193 & 8.706 & 94.06 & $\mathrm{R}$ \\
\hline Oswin & $9.9336^{\star}$ & $-0.0563^{\star}$ & $2.6632^{\star}$ & 0.5372 & 5.605 & 98.71 & $\mathrm{R}$ \\
\hline Sabbah & $41.1419^{\star}$ & $0.7656^{\star}$ & $0.2933^{*}$ & 0.7372 & 8.884 & 95.19 & B \\
\hline \multirow[t]{2}{*}{ Sigma Copace } & $0.5998^{*}$ & $0.7656^{\star}$ & $0.2933^{*}$ & 0.6132 & 7.548 & 96.67 & B \\
\hline & \multicolumn{7}{|c|}{ Adsorption } \\
\hline Chung-Pfost & $19.5641^{\star}$ & $3.3315^{\star}$ & $24.521^{\star}$ & 0.4006 & 4.766 & 97.78 & B \\
\hline Copace & $1.4054^{\star}$ & $0.007^{\star}$ & $1.5666^{\star}$ & 0.3517 & 4.738 & 98.29 & $\mathrm{R}$ \\
\hline $\mathrm{GAB}$ & $4.379 *$ & 29.5928 & $0.7638 *$ & 0.7260 & 9.298 & 92.74 & $\mathrm{R}$ \\
\hline Modified Halsey & $4.1753^{\star}$ & $0.0141^{\star}$ & $2.1146^{\star}$ & 0.4455 & 5.790 & 97.26 & B \\
\hline Modified Henderson & $0.00017^{\star}$ & $28.1965^{\star}$ & $2.0914^{\star}$ & 0.4251 & 4.967 & 97.51 & B \\
\hline Henderson & $0.00004^{*}$ & $2.0586^{\star}$ & - & 0.6588 & 8.390 & 94.02 & $\mathrm{R}$ \\
\hline Oswin & $8.7408^{*}$ & $-0.0479 *$ & $2.9406^{\star}$ & 0.3720 & 4.385 & 98.09 & $\mathrm{R}$ \\
\hline Sabbah & 32.1999* & $0.6747^{\star}$ & $0.2781^{*}$ & 0.5977 & 7.487 & 95.08 & B \\
\hline Sigma Copace & $0.6195^{\star}$ & $0.0067^{\star}$ & $0.9231^{*}$ & 0.4465 & 5.724 & 97.25 & B \\
\hline
\end{tabular}
Adzuki bean seeds (Almeida et al., 2013). The Copace model also had the lowest values of SE, which is indicative of a good

Table 3. Adjustment coefficients and statistical indices of the models tested to describe the hygroscopic equilibrium of Brazil nuts by desorption and adsorption

* - Significant using the $\mathrm{t}$ test at $\mathrm{p} \leq 0.01$; RD - Tendency of the residue distribution; R - Random; B - Biased; SE - Standard error; P - Mean relative error 


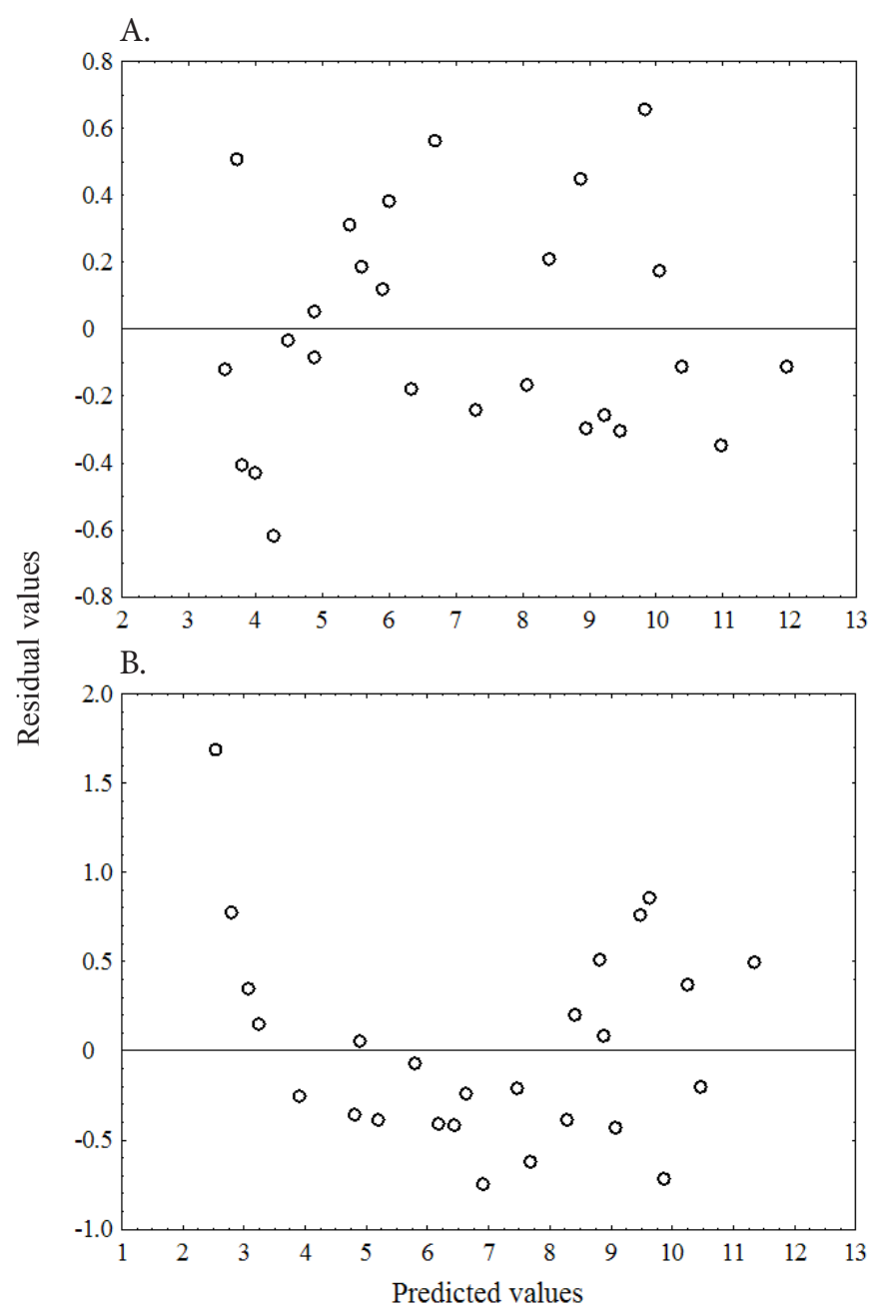

Figure 1. Examples of residue distributions observed in the present study, random (A) and biased (B)

correspondence between observed and estimated values (Draper \& Smith, 1998), as can be seen in Figure 2.

There is a temperature influence on the sorption isotherms of Brazil nuts, and it is possible to achieve similar moisture contents by increasing temperature with incremental water activity; similarly, at a constant water activity, equilibrium moisture content diminishes with increasing temperatures (Figure 2). This trend is observable in the isotherms of most agricultural products (Smaniotto et al., 2012; Oliveira et al., 2014).

One of the most important reasons to describe sorption isotherms of an agricultural product is to be able to recommend moisture contents that allow safe storage, especially regarding fungal development. For Brazil nuts, this is particularly important because one of the main problems associated with commercialization of this product in Brazil is the presence of aflatoxin, produced by Aspergillus species during metabolism. The Brazil nut season coincides with the rainy season in the Amazon region, with the product subjected to several days, or even months, in the forest under environmental conditions favorable to fungal development before being collected. Fungi require a minimum water activity around of 0.7 to develop in foodstuffs under optimal temperature conditions $\left(26-30{ }^{\circ} \mathrm{C}\right)$ (Christensen \& Kaufmann, 1974; Afonso Júnior et al., 2003). Thus, based on analysis of desorption and adsorption data, the

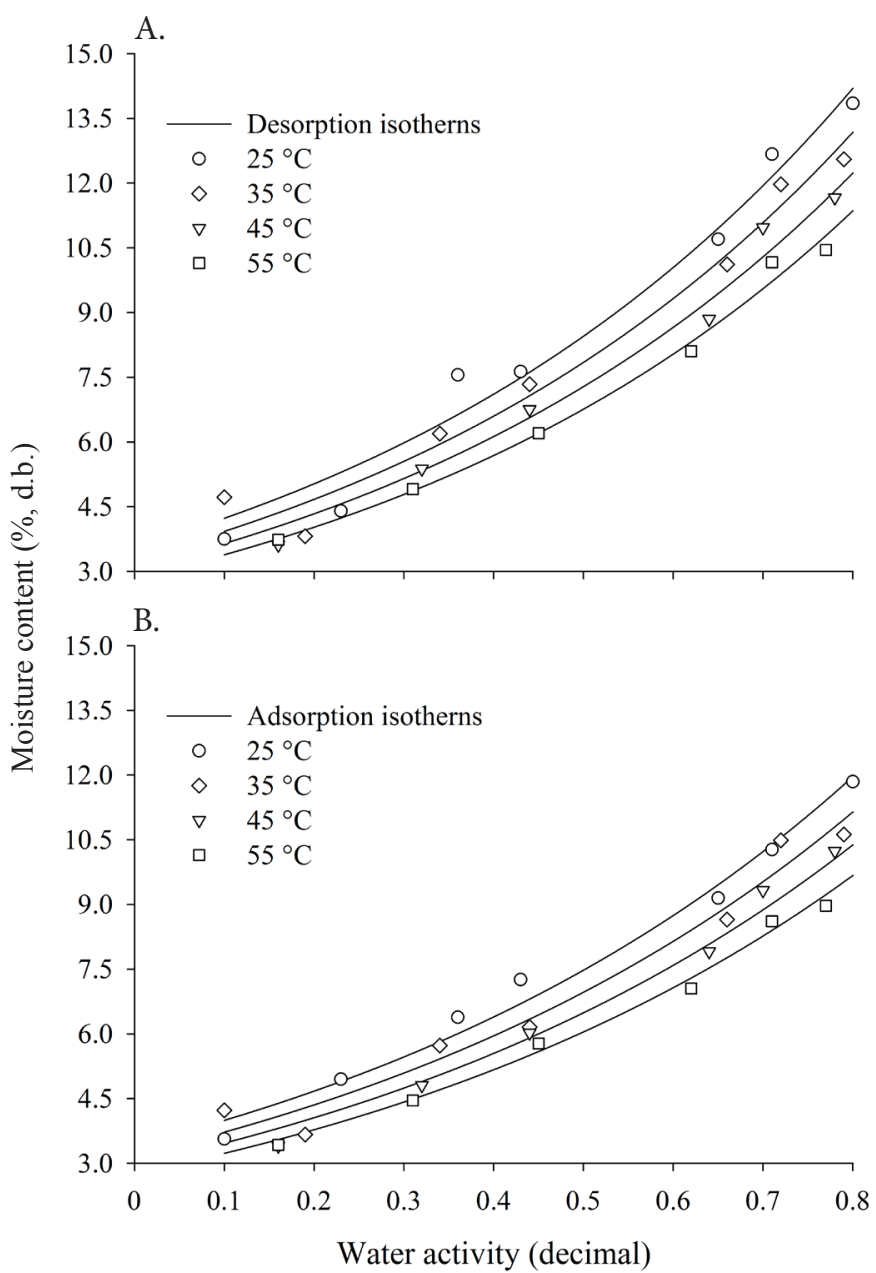

Figure 2. Observed values and sorption isotherms of Brazil nut seeds using the Copace model, obtained for desorption (A) and adsorption (B)

major value of moisture content that would assure non-growth of fungi in Brazil nut seeds would be $8.2 \%$ (d.b.).

Comparing the values of equilibrium moisture content obtained for both desorption and adsorption (Figure 2), it can be seen that under the same psychrometric air conditions, values obtained for desorption were always higher than those for adsorption. Differences between moisture content values obtained by desorption and adsorption are known as hysteresis, a phenomenon usually observed in agricultural products (Mohsenin, 1986) and Brazil nuts (Figure 3).

Although hysteresis was observed throughout the water activity range, if considered in a specific isotherm, it was more pronounced for higher values of water activity. Specialized literature reports a wide range of reasons regarding the effects of water activity on hysteresis. This phenomenon occurs in a pronounced way during the entire range of water activity; in other words, at lower, intermediate and higher values of water activity (Pena et al., 2010; Corrêa et al., 2014; Goneli et al., 2016), suggesting that this effect depends on the product under study. The effect of temperature on hysteresis, on the other hand, was the inverse of the water activity behavior. This phenomenon became more evident at lower temperatures, a trend commonly observed in grain and seeds (Pena et al., 2010; Miranda et al., 2012; Corrêa et al., 2014; Rodovalho et al., 2015; Campos et al., 2016; Goneli et al., 2016), suggesting that this trend is a characteristic of the sorption process itself. 


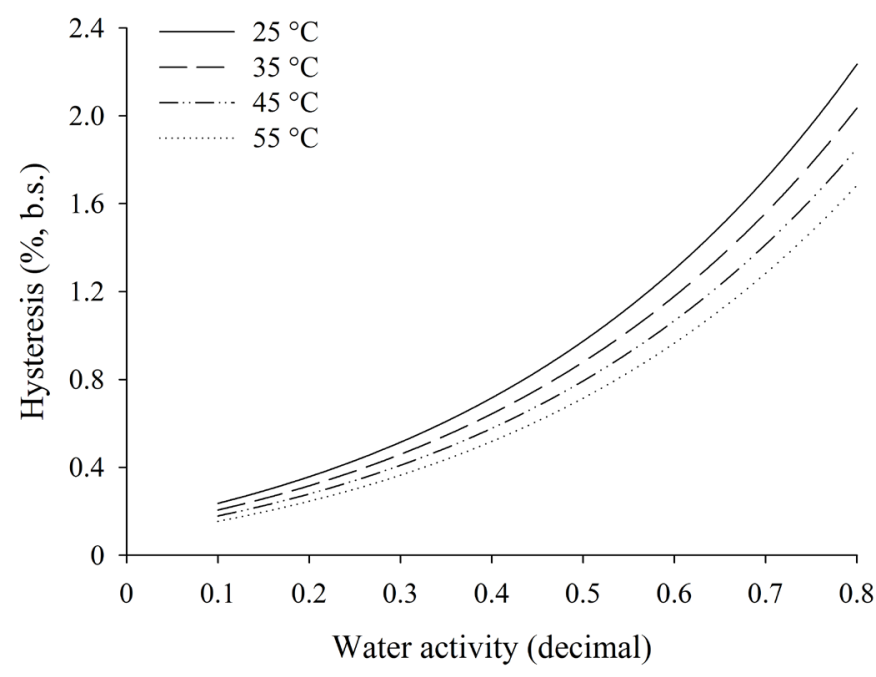

Figure 3. Hysteresis in Brazil nut seeds as a function of water activity at four air temperatures

The phenomenon of hysteresis occurs because under high moisture conditions, sorption sites in the molecular structure of the material are almost filled with water (Mohsenin, 1986). According to this author, after the drying process, the number of sorption sites available decreases owing to the product's shrinkage, leading to a reduction in the material's capacity to bond with water molecules under future adsorption.

\section{Conclusions}

1. Hygroscopicity of Brazil nuts presents similar characteristics to most agricultural products already studied, so that for the water activity values used at this work (between 0.1 and 0.8 ), the equilibrium moisture content decreases with temperature increment and, for a certain air temperature (between 25 and $55^{\circ} \mathrm{C}$ ), the moisture content increases with increases in water activity.

2. The Copace, Henderson and Oswin models are suitable to describe the sorption isotherms of Brazil nut seeds.

3. The moisture content value for storage at temperatures below $55^{\circ} \mathrm{C}$, without the risk of fungal development, must be lower than $8.2 \%$ (d.b.).

4. The hysteresis increases as the water activity increases mainly at lower temperature values.

\section{Literature Cited}

Afonso Júnior, P. C.; Corrêa, P. C.; Silva, F. S. da; Ribeiro, D. M. Atividade de água, crescimento microbiológico e perda de matéria seca dos grãos de café (Coffea arabica L.) em diferentes condições de armazenamento. Revista Brasileira de Produtos Agroindustriais, v.5, p.17-24, 2003. https://doi.org/10.15871/15178595/rbpa.v5n1p17-24

Almeida, D. P.; Resende, O.; Costa, L. M.; Mendes, U. C. Higroscopicidade das sementes de feijão adzuki. Científica, v.41, p.130-137, 2013.

Bayma, M. M. A.; Malavazi, F. W.; Sá, C. P. de; Fonseca, F. L.; Andrade, E. P.; Wadt, L. H. de O. Aspectos da cadeia produtiva da castanhado-Brasil no estado do Acre, Brasil. Boletim do Museu Paraense Emílio Goeldi, v.9, p.417-426, 2014.
Brasil. Ministério da Agricultura e Reforma Agrária. Regras para análise de sementes. Brasília: MAPA, 2009. 398p.

Campos, R. C.; Corrêa, P. C.; Fernandes, L. S.; Baptestini, F. M.; Costa, C. F.; Bustos-Vanegas, J. D. Bean grain hysteresis with induced mechanical damage. Revista Brasileira de Engenharia Agrícola e Ambiental, v.20, p.930-935, 2016. https://doi.org/10.1590/18071929/agriambi.v20n10p930-935

Corrêa, P. C.; Botelho, F. M.; Botelho, S. de C. C.; Goneli, A. L. D. Isotermas de sorção de água de frutos de Coffea canephora. Revista Brasileira de Engenharia Agrícola e Ambiental, v.18, p.1047-1052, 2014. https://doi.org/10.1590/1807-1929/agriambi. v18n10p1047-1052

Corrêa, P. C.; Reis, M. F. T.; Oliveira, G. H. H. de; Oliveira, A. P. L. R. de; Botelho, F. M. Moisture desorption isotherms of cucumber seeds: Modeling and thermodynamic properties. Journal of Seed Science, v.37, p.218-225, 2015. https://doi.org/10.1590/2317$1545 \mathrm{v} 37 \mathrm{n} 3149549$

Costa, L. M.; Resende, O.; Oliveira, D. E. C. de. Isotermas de dessorção e calor isostérico dos frutos de crambe. Revista Brasileira de Engenharia Agrícola e Ambiental, v.17, p.412-418, 2013. https:// doi.org/10.1590/S1415-43662013000400009

Christensen, C. M.; Kaufmann, H. H. Microflora. In: Christensen, C. M. Storage of cereal grain and their products. St. Paul: American Association of Cereal Chemists, 1974. p.158-192.

Draper, N. R.; Smith, H. Applied regression analysis. 3.ed. New York: John Wiley \& Sons, 1998. 712p. https://doi. org/10.1002/9781118625590

FAO - Food and Agriculture Organization. Available on: $<$ http://www. fao.org/faostat/en/\#compare >. Accessed on: Apr. 2017.

Goneli, A. L. D.; Corrêa, P. C.; Oliveira, G. H. H. de; Botelho, F. M. Water desorption and thermodynamic properties of okra seeds. Transactions of the American Society of Agricultural and Biological Engineers, v.53, p.191-197, 2010. https://doi. org/10.13031/2013.29486

Goneli, A. L. D.; Corrêa, P. C.; Oliveira, G. H. H. de; Resende, O.; Mauad, M. Moisture sorption isotherms of castor beans. Part 1: Mathematical modeling and hysteresis. Revista Brasileira de Engenharia Agrícola e Ambiental, v.20, p.751-756, 2016. https:// doi.org/10.1590/1807-1929/agriambi.v20n8p751-756

Henao, J. D.; Queiroz, M. R. de; Haj-Isa, N. M. A. Umidade de equilíbrio de café cereja descascado baseadas em métodos estático e dinâmico. Revista Brasileira de Engenharia Agrícola e Ambiental, v.13, p.470-476, 2009. https://doi.org/10.1590/S141543662009000400015

Madamba, P. S.; Driscoll, R. H.; Buckle, K. A. The thin-layer drying characteristics of garlic slices. Journal of Food Engineering, v.29, p.75-97, 1996. https://doi.org/10.1016/0260-8774(95)00062-3

Miranda, M.; Vega-Gálvez, A.; Sanders, M.; López, J.; LemusMondaca, R.; Martínez, H.; Scala, K. di. Modelling the water sorption isotherms of quinoa seeds (Chenopodium quinoa Willd.) and determination of sorption heats. Food and Bioprocess Technology, v.5, p.1686-1693, 2012. https://doi.org/10.1007/ s11947-011-0610-y

Mohapatra, D.; Rao, P. S. A thin layer drying model of parboiled wheat. Journal of Food Engineering, v.66, p.513-518, 2005. https://doi. org/10.1016/j.jfoodeng.2004.04.023

Mohsenin, N. N. Physical properties of plant and animal materials. New York: Gordon and Breach Publishers, 1986. 841p. 
Oliveira, D. E. C. de; Resende, O.; Campos, R. C.; Donadon, J. R. Obtenção e modelagem das isotermas de dessorção e do calor isostérico para sementes de arroz em casca. Científica, v.42, p.203-210, 2014. https://doi.org/10.15361/19845529.2014v42n3p203-210

Pena, R. S. da; Mendonça, N. B.; Almeida, M. D. C. de. Comportamento higroscópico do açaí em pó. Revista Brasileira de Produtos Agroindustriais, v.12, p.153-161, 2010. https://doi. org/10.15871/1517-8595/rbpa.v12n2p153-161

Rodovalho, R. S.; Silva, I. L.; Silva, H. W. da; Rosetto, C. A. V. Isotermas de sorção dos grãos de pimenta bode. Revista Agrotecnologia, v.6, p.80-101, 2015. https://doi.org/10.12971/2179-5959/ agrotecnologia.v6n1p80-101
Rosa, G. S.; Moraes, M. A.; Pinto, L. A. A. Moisture sorption properties of chitosan. LWT - Food Science and Technology, v.43, p.415-420, 2010. https://doi.org/10.1016/j.lwt.2009.09.003

Smaniotto, T. A. de S.; Resende, O.; Oliveira, D. E. C. de; Sousa, K. A. de; Campos, R. C. Isotermas e calor latente de dessorção dos grãos de milho da cultivar AG 7088. Revista Brasileira de Milho e Sorgo, v.11, p.312-322, 2012. https://doi.org/10.18512/1980-6477/ rbms.v11n3p312-322

Sousa, K. A. de; Resende, O.; Costa, L. M. Isotermas de dessorção das sementes de nabo forrageiro obtidas pelos métodos dinâmico e estático. Revista Brasileira de Engenharia Agrícola e Ambiental, v.17, p.216-222, 2013. https://doi.org/10.1590/S141543662013000200013 